\title{
Ser80lle mutation and a concurrent Pro25Leu variant of the VHL gene in an extended Hungarian von Hippel-Lindau family
} Attila Patocs 1 , Peter Gergics'2, Katalin Balogh2 ${ }^{2}$, Miklos Toth ${ }^{2}$, Ferenc Fazakas 3 , Istvan Liko ${ }^{4}$ and Karoly Racz*2

Address: ${ }^{1}$ Molecular Medicine Research Group, Hungarian Academy of Sciences and Semmelweis University, Szentkirályi 46, H-1088 Budapest, Hungary, ${ }^{2}$ nd Department of Medicine, Faculty of Medicine, Semmelweis University, Szentkirályi 46, H-1088 Budapest, Hungary, ${ }^{3}$ Medical and Health Science Center, University of Debrecen, H-4200, Debrecen, Hungary and ${ }^{4}$ Richter Gedeon LTD, Budapest, Hungary

Email: Attila Patocs - patatt@bel2.sote.hu; Peter Gergics - gerpet@yahoo.com; Katalin Balogh - bkatus@freemail.hu; Miklos Toth - totmik@bel2.sote.hu; Ferenc Fazakas - wolfrick@smart.dote.hu; Istvan Liko - I.Liko@ richter.hu; Karoly Racz* - racz@bel2.sote.hu * Corresponding author

Published: 16 April 2008

BMC Medical Genetics 2008, 9:29 doi:10.1 186/1471-2350-9-29
Received: 26 October 2007

Accepted: 16 April 2008

This article is available from: http://www.biomedcentral.com/I47I-2350/9/29

(c) 2008 Patocs et al; licensee BioMed Central Ltd.

This is an Open Access article distributed under the terms of the Creative Commons Attribution License (http://creativecommons.org/licenses/by/2.0), which permits unrestricted use, distribution, and reproduction in any medium, provided the original work is properly cited.

\begin{abstract}
Von Hippel-Lindau disease (VHL) is a rare autosomal dominant disease characterized by development of cystic and tumorous lesions at multiple sites, including the brain, spinal cord, kidneys, adrenals, pancreas, epididymis and eyes. The clinical phenotype results from molecular abnormalities of the $V H L$ tumor suppressor gene, mapped to human chromosome 3p25-26. The $\mathrm{VHL}$ gene encodes two functionally active VHL proteins due to the presence of two translational initiation sites separated by 53 codons. The majority of disease-causing mutations have been detected downstream of the second translational initiation site, but there are conflicting data as to whether few mutations located in the first 53 codons, such as the Pro25Leu could have a pathogenic role. In this paper we report a large Hungarian VHL type 2 family consisting of 32 members in whom a disease-causing AGT80AAT (Ser80lle) c.239G >A, p.Ser80lle mutation, but not the concurrent CCT25CTT (Pro25Leu) c.74C>T, p.Pro25Leu variant co-segregated with the disease. To our knowledge, the Ser80lle mutation has not been previously described in VHL type 2 patients with high risk of pheochromocytoma and renal cell cancer. Therefore, this finding represents a novel genotype-phenotype association and VHL kindreds with Ser80lle mutation will require careful surveillance for pheochromocytoma. We concluded that the Pro25Leu variant is a rare, neutral variant, but the presence such a rare gene variant may make genetic counseling difficult.
\end{abstract}

\section{Background}

Von Hippel-Lindau disease (VHL) (OMIM nr. 193300) is a rare autosomal dominant multi-organ disease caused by molecular abnormalities of the VHL tumor suppressor gene [1]. Patients with VHL are at risk for development of retinal, cerebellar, spinal, pancreatic and renal hemangioblastomas, pulmonary and liver hemangiomas, clear- cell renal carcinomas, pheochromocytomas, endolymphatic sac tumors, multiple renal, epididymal and pancreatic cysts, cystadenomas of the epididymis and of the broad ligament, and pancreatic islet cell tumors [1-3]. Based on the presence or absence of pheochromocytoma, two main subtypes of the VHL disease have been identified. Patients with VHL type 1 are at risk to develop renal 
cell carcinoma and hemangioblastoma but predominantly without pheochromocytoma, while those with VHL type 2 may have all manifestations of the disease predominantly including pheochromocytoma. VHL type 2 has been subdivided into subtype $2 \mathrm{~A}$ and $2 \mathrm{~B}$, with a low and high risk of renal cell carcinoma, respectively, whereas subtype $2 \mathrm{C}$ is a pheochromocytoma-only phenotype. The prevalence of the VHL disease varies between 1:39,000 in Germany and 1:53,000 in East Anglia [4,5]. Manifestations of the disease show variable expression and several patients may have only one manifestation [4].

The human VHL gene maps to chromosome 3p25-26 [1]. As predicted by Knudson's two-hit model, tumor development requires inactivation of both copies; the first hit, the germline mutation or deletion is followed by somatic alterations usually detected as loss of heterozygosity. The $V H L$ gene has two translational initiation sites separated by 53 codons. Of the two proteins encoded by the VHL gene, the larger one contains 213 amino acids (pVHL30), whereas the shorter protein consists of 160 amino acids (pVHL18). Both proteins are functionally active and they share the same mechanism of tumor suppressor activity [6-8]. The VHL proteins form a multimeric complex with Elongin B, Elongin C, Cul2 and Rbx1. This complex is involved in ubiquitin-dependent proteolysis of large cellular proteins via controlled degradation of $\alpha$-subunits of the heterodimeric transcription factor hypoxia inducible factor (HIF) $[9,10]$. In addition, complexes containing pVHL, Elongin B, Elongin C, Cul2 and Rbx1 target proteins are involved in cell-cycle regulation for degradation, suggesting that pVHL has a possible role in cell-cycle exit [11]. In 1999, Stebbins and co-workers presented the three-dimensional protein structure of the VHL-ElonginCElongin B complex. They identified two functionally active sites; the ElonginC binding site in the $\alpha$-helical domain involving residues between amino acids 157 and 170, and the HIF binding site in the $\beta$-sheet domain from residue 91 to $113[8]$.

The majority of VHL patients have deletions, insertions, or mutations downstream of the second translational initiation site located at codon 54 of the VHL gene. Interestingly, missense mutations encoding residues of the protein binding sites have been associated with VHL type 2 , whereas VHL type 1 is caused either by missense or nonsense mutations affecting the hydrophobic core, or by partial gene deletions which result in a complete defect of protein function. It has been also demonstrated that some mutant pVHL, which are associated with the type $2 \mathrm{C}$ phenotype, may impair fibronectin matrix assembly while they retain the ability to down regulate HIF [12].

Because mutations affecting the first 53 codons of the VHL gene have no effect on the structure of the shorter VHL protein, it seemed particularly interesting to clarify whether these mutations could exert a pathogenic effect. In one study the Pro25Leu variant has been associated with a sporadic pheochromocytoma [13]. but other studies involving a limited number of cases failed to confirm the pathogenic role of this variant $[14,15]$. In this paper we report a large Hungarian VHL type 2 family with a disease-causing AGT80AAT (Ser80Ile) c.239G>A, p.Ser80Ile mutation and a concurrent CCT25CTT (Pro25Leu) c.74C $>$ T, p.Pro25Leu variant (identification number: rs35460768 (dbSNP127) of the VHL gene. We show that in family members the Ser80Ile mutation, but not the Pro25Leu variant co-segregated with the disease. In order to confirm the pathogenicity of the Ser80Ile mutation and to test whether the Pro25Leu variant might be neutral, an evolutionary multiple sequence alignment analysis (MSA) combined with a Align GVGD was.performed. Threedimensional modeling of the Ile80-mutant protein is also presented.

\section{Patients and methods \\ Patients and data collection}

A large Hungarian VHL type 2 family spanning five generations and involving 32 members (Fig 1 ) was evaluated at the $2^{\text {nd }}$ Department of Medicine, Faculty of Medicine, Semmelweis University in Budapest, Hungary. Initial screening included medical history, physical examination, abdominal ultrasonography, abdominal and brain computed tomography (CT) or magnetic resonance imaging (MRI), ophthalmologic examination, routine biochemical testing and 24-h urinary catecholamine metabolite determinations.

\section{Screening for VHL gene mutations}

Written informed consent was obtained from all family members who participated in the study. Genomic DNA was extracted from peripheral blood leukocytes using DNA isolation kit for mammalian blood samples (Boehringer Mannheim Corporation, Indianapolis, IN). Mutation analysis of the VHL gene was performed as previously described [16].

\section{Evolutionary alignment analysis of the VHL protein}

Multiple sequence alignment (MSA) of protein sequences was performed using 3D-coffee, a freely available webbased tool for aligning multiple sequences [17]. A total of eight sequences: Mus musculus (ENSMUSG0000003393 3 ), Rattus norvegicus (ENSRNOG00000010258), Canis familiaris (ENSCAFG00000005149), Homo sapiens (EN ST00000256474), Gallus gallus (ENSGALG0000000136 78 ), and evolutionary more distant species including Drosophila melanogaster (CG13221_CG13221-RA), Xenopus tropicalis (ENSXET00000001448) and Takifugu rubripes (SINFRUG00000121189) were analysed. 


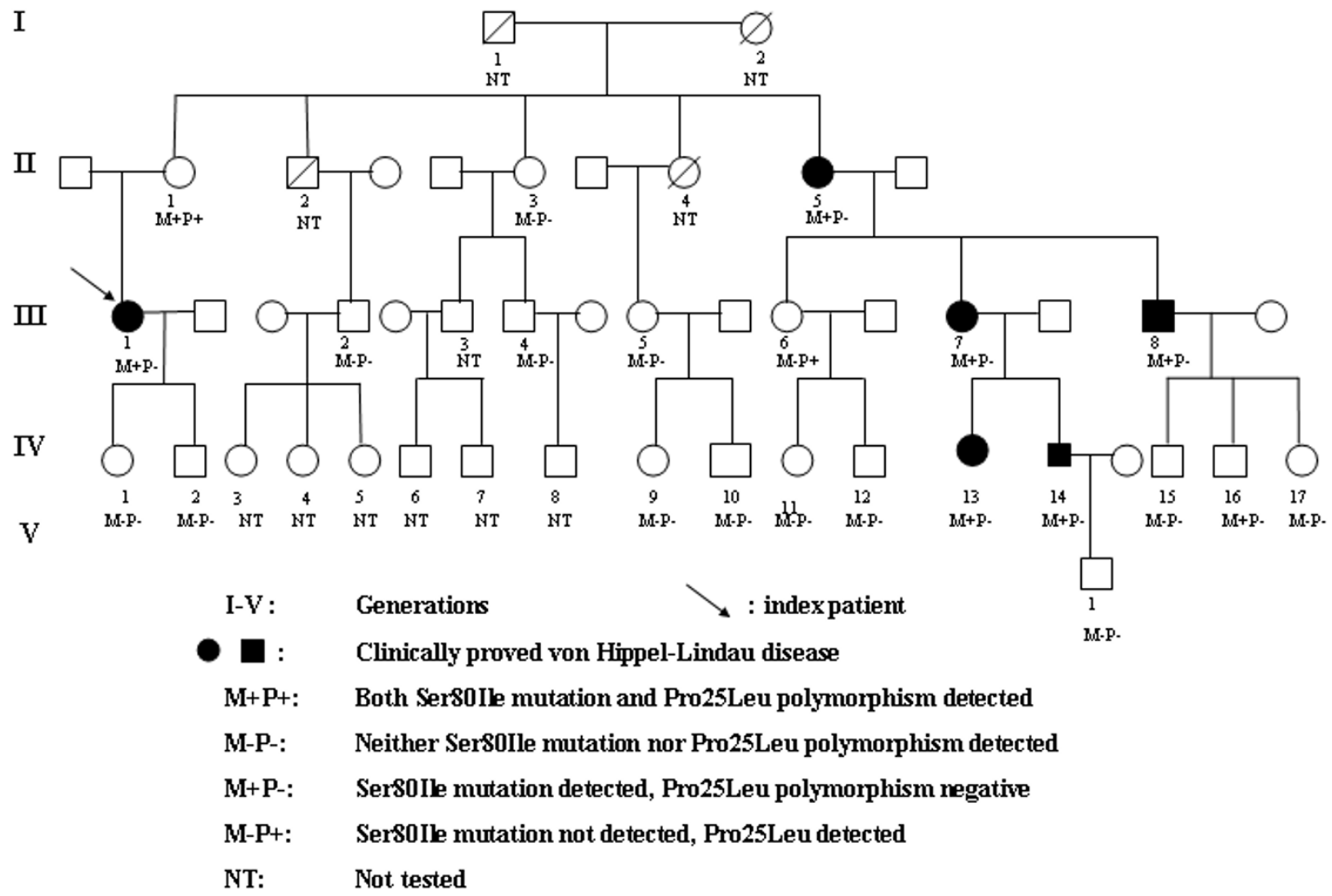

Figure I

Pedigree of a Hungarian kindred with von Hippel-Lindau disease.

One popular method for measuring biochemical distances between pairs of amino acids is the Grantham Difference (18), which takes into account the composition, polarity and volume of mutant and wild-type amino acids. In this study, we have constructed a VHL protein MSA and combined a conservation score (GV) with a measure of biochemical difference between wild-type and mutant residues with respect to the alignment (GD). This extension of the Grantham Difference, called Align GVGD, has previously been successfully applied to BRCA1 and TP53 genes $(19,20)$. Align GVGD is freely available online (21).

Three-dimensional structure modeling of the VHL protein The coordinates of the pVHL were obtained from $1 \mathrm{vcb}$ _a.pdb structure file [8]. The three-dimensional image was generated with Swiss-PdbViewer in combination with POV-Ray [22].

\section{Results}

\section{Genotype-phenotype associations}

The index patient was operated for pheochromocytoma and renal cell carcinoma diagnosed at the age of $34 \mathrm{yr}$ and $40 \mathrm{yr}$, respectively. She also developed a brain hemangioblastoma at the age of $42 \mathrm{yr}$. Genetic screening indicated that she had a heterozygous AGT80AAT (Ser80Ile) c.239G >A, p.Ser80Ile mutation of the VHL gene. The 70yr-old mother of the index patient proved to be not only a gene carrier for the Ser80Ile mutation, but she also had the CCT25CTT (Pro25Leu) c.74C>T, p.Pro25Leu variant (identification number: rs35460768 (dbSNP127)), both in heterozygous forms. However, the mother showed no clinical, biochemical or radiological evidence of VHLassociated tumors. The absence of the Pro25Leu variant in the index patient indicated, that the Ser80Ile mutation and the Pro25Leu variant in the mother were present in separate alleles.

In addition to the index patient and her mother, the Ser80Ile mutation was detected in other 5 members of the 
family (III/7, III/8, IV/13, IV/14 and IV/16) (Fig 1), of which all but one member (III/7, III/8, IV/13 and IV/14) had clinical manifestations of the disease.

Importantly, pheochromocytomas were identified in family members III/ 8 and IV/14, of whom, in patient IV/14 this was the first sign of the disease manifested at the age of 10 years and involved both adrenals. Other typical manifestations included brain hemangioblastomas in family members: III/7, III/ 8 and IV/13, retina hemangioblastomas in family members III/7, III/8, IV/13 and IV/14, and renal cysts in family member IV/13. In addition, family history revealed that one sister of the mother of the index patient (II/5) died due to bilateral renal cell carcinomas. Another sister of the mother of the index patient (II.4) died because of a metastatic pancreatic tumor without histological confirmation and, therefore, this family member was not considered as having VHL. The age, clinical manifestations, and the age at diagnosis of VHL-associated lesions in carriers of the Ser80Ile mutation and in those with clinically proven VHL-associated tumors are summarized in Table 1.

In addition to the mother of the index patient, the Pro25Leu variant was detected on another family member (III/6) (Fig 1), who was clinically healthy.

The prevalence of the Pro25Leu variant was tested in 16 members of other 8 VHL families and in 39 patients with sporadic pheochromocytomas, but none of the patients had this variant.

\section{Evolutionary alignment analysis of the VHL gene}

As shown in Fig. 2., the Ser at amino acid position 80 represents a highly conserved amino acid residue among different species, including rat, mouse, dog, chicken and an evolutionary more distant species, Xenopus tropicalis. By contrast, the Pro at amino acid position 25 failed to show a conserved pattern. Using Align-GVGD criteria both variants were predicted as neutral fulfilling the criteria $0<\mathrm{GV}$ $\leq 61,3$ and GD>0 (the calculated GV and GD scores for Pro25Leu polymorphism were 218.82 and 4.86 and for Ser80Ile 219.56 and 3.24, respectively).

\section{Effect of change of Ser80 to Ile80 on protein structure}

The three-dimensional model of the pVHL is available from residue Met54, which allowed us to analyse functional consequences of the Ser80Ile mutation using a three-dimensional computational modeling. The CPK diagram in Fig. 3 illustrates both the wild-type Ser80 and the mutant Ile80 proteins. The Ser80 residue makes tight junctions with Pro103 and Ile151 by hydrogen-bonds between the amino group of Ser80 and the carboxyl oxygen of Pro103 and Ile151. The Ser80 residue is located on the same side where ElonginC binds, and residues Pro81 and Arg82 are involved in direct binding. The Asn78 residue from the $\beta$-domain, together with hydrophobic core residues (Pro86, Phe76, Phe119, Trp117 and Val130) have important roles for structural integrity of the $\beta$-sandwich [8]. A change of Ser to Ile at position 80 disturbs this integrity of the $\beta$-sandwich due to a change in the orientation of the Arg82 residue, which disturbs its linker role and, consequently, the hydrogen bond between Arg82 and Leu153 disappears. It has been already demonstrated that the Arg82 residue plays a central role in structural integrity of the pVHL, as it makes significant hydrogenbond contacts with Leu153, Val155, Lys159 and Arg161 and, through these contacts; it is involved in interactions between pVHL and ElonginC [8].

\section{Discussion}

In this paper we describe a large Hungarian VHL type 2 family consisting of 32 members, in whom a disease-causing AGT80AAT (Ser80Ile) c.239G>A, p.Ser80Ile mutation

Table I: Clinical manifestations of VHL disease in carriers of the Ser80lle mutation and/or the Pro25Leu variant and in those with clinically proven VHL-associated tumors

\begin{tabular}{|c|c|c|c|c|c|c|}
\hline $\begin{array}{c}\text { Family member } \\
\text { (age, years) }\end{array}$ & $\begin{array}{c}\text { Renal cell } \\
\text { carcinoma (age } \\
\text { at presentation, } \\
\text { years) }\end{array}$ & $\begin{array}{l}\text { Brain heman- } \\
\text { gioblastoma } \\
\text { (age at } \\
\text { presentation, } \\
\text { years) }\end{array}$ & $\begin{array}{l}\text { Pheochromo- } \\
\text { cytoma (age at } \\
\text { presentation, } \\
\text { years) }\end{array}$ & $\begin{array}{l}\text { Retina heman- } \\
\text { gioblastoma } \\
\text { (age at } \\
\text { presentation, } \\
\text { years) }\end{array}$ & $\begin{array}{l}\text { Other clinical } \\
\text { manifestations }\end{array}$ & $\begin{array}{l}\text { Result of } \\
\text { genetic } \\
\text { screening }\end{array}$ \\
\hline II/I (70) & - & - & - & - & - & Pro25Leu Ser80lle \\
\hline III/6 (44) & - & - & - & - & - & Pro25Leu \\
\hline II/5 (63) & + bilateral (45) & - & - & - & & ND \\
\hline III/I* (42) & + bilateral (40) & $+(42)$ & $+(34)$ & - & - & Ser80lle \\
\hline III/7 (47) & - & $+(37)$ & - & $+(18)$ & - & Ser80lle \\
\hline III/8 (39) & - & $+(38)$ & $+(39)$ & $+(29)$ & - & Ser80lle \\
\hline IV/I3 (27) & - & $+(22)$ & - & $+(23)$ & renal cysts $(20)$ & Ser80lle \\
\hline IV/I4 (26) & - & - & + bilateral (I0) & $+(26)$ & - & Ser80lle \\
\hline IV/I6 (16) & - & - & - & - & - & Ser80lle \\
\hline
\end{tabular}

*, index patient; -, present; +, absent; ND, not determined (DNA for genetic testing was not available) 
Homo sapiens

Canis familiaris

Rattus norvegicus

Mus musculus

Xenopus tropicals

Drosophila melanogaster

Gallus gallus

Takifugu rubripes

Homo sapiens

Canis familiaris

Rattus norvegicus

Mus musculus

Xenopus tropicals

Drosophila melanogaster

Gallus gallus

Takifugu rubripes

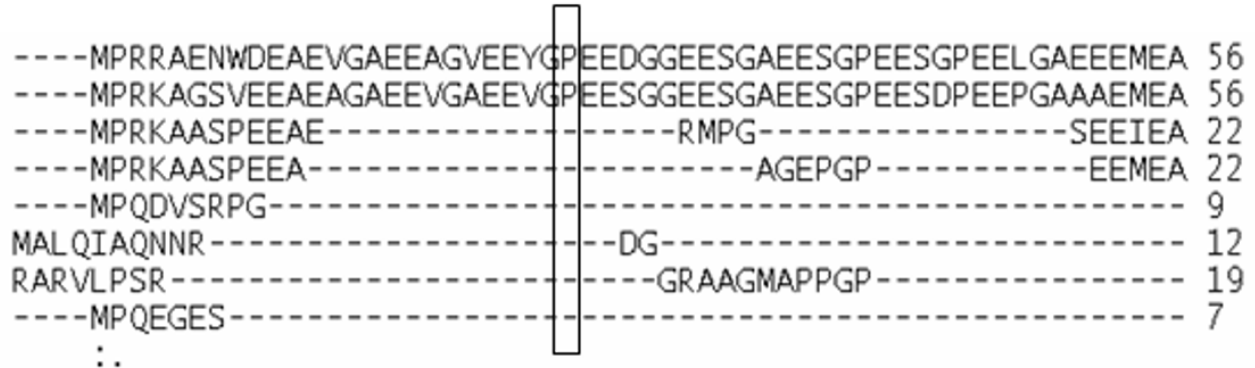

GRPRPVLRSVNSREPSQVIFCNRSPRWLPWLNFDGEPQPYPTLPPGTGRRIHSYRGHL 116 GQPRPVLRSVNSCEPSQVIFCNR SPRWLPWLNFDGEPQPYSTLPPGTGRRIHSYRGHL 116 GRPRPVLRSVNSREPSQVIFCNR SPRWLPLWLNFDGEPQPYPTLPPGTGRRIHSYRGHL 82 GRPRPVLRSVNSREPSQVIFCNR SPRWLPLWLNFDGEPQPYPILPPGTGRRIHSYRGHL 82 --SVPQLRSFNSRQPVQWFCNRSTRTVQPIWNNFQGDPQSYPTLPAGSGRRMNTYLGHI 67 ---QQLVGADQGKVEWLFANTT /RTLDL WWCERERENMYLTLKPFEEVRVNTFTTHS 69 GPAGPCLRSANTRELSEWFNNRSPRAVLPIWDFEGRPRYYPVRPRTGRIMHSYRGHL 79 --SLPLVRSLNSRIPIVAVFCNRTPRWRPWIDFFGHPQGVDELQPGTGRRMTTFVGHP 65

\section{Figure 2}

Alignment analysis of the VHL protein from Mus musculus (ENSMUSG00000033933), Rattus norvegicus (ENSRNOG000000 10258), Canis familiaris (ENSCAFG00000005 I49), Homo sapiens (ENST00000256474), Gallus gallus (ENSGALG0000000 I3678), Drosophila melanogaster (CGI322I_CGI322I-RA), Xenopus tropicalis (ENSXET0000000I448) and Takifugu rubripes (SINFRUG00000I2I I89).

and a concurrent CCT25CTT (Pro25Leu) c.74C>T, p.Pro25Leu variant were identified. Screening of family members indicated that 7 family members had the Ser80Ile mutation and 2 members had the Pro25Leu variant, and that the two genetic alterations were transmitted in separate alleles. More importantly, we showed that the Ser80Ile mutation, but not the Pro25Leu variant co-segregated with the VHL type 2 phenotype and that the Pro25Leu variant never occurred in family members who had manifestations of the disease. However, one family member who had both genetic alterations and one member with the Ser80Ile mutation without the Pro25Leu variant showed no manifestations of the disease, suggesting that this variant is not pathogenic for VHL.

In order to predict the pathological role of the Pro25Leu and Ser80Ile variants, first we constructed a multiple sequence alignment using evolutionary distant species. It has been shown previously that the addition of more distantly related sequences is essential for a more accurate prediction (20). However, in our case this approach revealed that both variants might be neutral, which is in contrast with earlier clinical findings suggesting the disease causing role of the Ser80Ile but not of the Pro25Leu. The Ser80Ile has been previously reported only in one VHL patient without clear cell renal carcinoma [23], but several other missense mutations at codon 80 have been described. The Ser80Gly mutation has been detected in a 12 -yr-old patient with bilateral pheochromocytomas and multiple congenital malformations [24] and in a patient with pheochromocytoma [25]. The Ser80Asn mutation was identified in a Slovakian family with VHL type 1 phenotype including pancreatic islet tumor in one affected individual [26]. In addition, the pathogenic role of Ser80Arg $[27,28]$ and Ser80Asn mutations has been also documented in VHL patients [25]. Our study shows for the first time that the Ser80Ile mutation is associated with bilateral pheochromocytoma presented as a first manifestation of the disease, which points out that VHL patients harboring this mutation require careful screening for pheochromocytoma.

The association between various missense mutations at codon 80 of the VHL gene and VHL disease in previous studies and ours is not unexpected, since our evolutionary alignment analysis showed that in this position the Ser is a highly conserved amino acid residue among different species. Moreover, computational protein modeling of a change of Ser to Ile at position 80 indicated potentially important consequences on three-dimensional structure of the pVHL. Ser80 is a polar amino acid located in the hydrophobic core of the $\beta$-domain close to the $\alpha-\beta$ interface of pVHL and ElonginC interaction. According to our protein modeling, the change of Ser to a larger and non- 

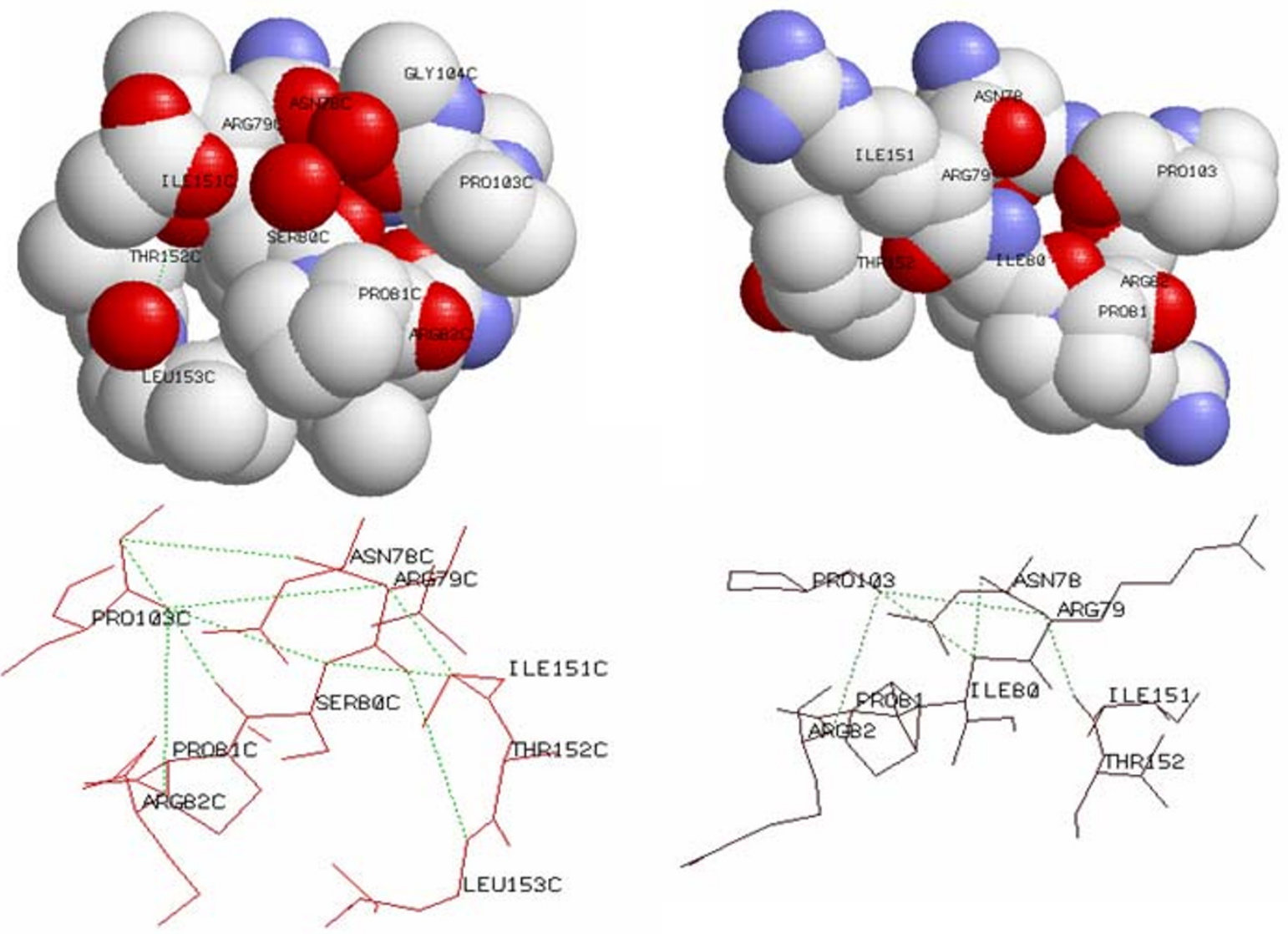

Figure 3

Three-dimensional computational modeling of the Ser80 and Ile80 residues using CPK diagram (upper part) and schematic representation of hydrogen-bonds between residues Gly 104 and Asn78, between Arg79 and Ile I 5 I, between Ser80 and Ile I 5 I, beween Ser80 and Prol 03, between Ser80 and Leu I 53, and between Prol 03 and Arg82 in wild type pVHL and the consequences of the Ser to lle change at amino acid position 80 (lower part). All figures were generated with Swiss-PdbViewer in combination with POV-Ray.

polar Ile at amino acid position 80 results in a complex rearrangement of the three-dimensional structure of the protein binding interface, which disturbs HIF1 $\alpha$ and fibronectin binding [29]. Miller and co-workers have already demonstrated that $V H L$ gene mutations within L1 and L7 loops distrupt the dynamic coupling of the pVHL and HIF- $1 \alpha$ and that this may be an important mechanism for the development of tumors [30]. Other studies using three-dimensional modeling and a computer algorithm FOLDEF provided a quantitative estimation of the importance of the interactions contributing to the stability of proteins and protein complexes [31]. In the case of the Ser80Ile, the free energy difference between the wild type and mutant proteins was $12.2 \mathrm{kcal} / \mathrm{mol}$, which is higher than the previously established cut-off value for the development of clear-cell renal carcinoma or pheochromocytoma [32].

Although mutations affecting the first 53 codons of the $V H L$ gene have no effect on the structure of the shorter VHL protein, a few mutations at codons 25, 38, 46 and 52 have been considered to exert a pathogenic role. The Pro25Leu and Ser38Pro have been identified in patients with pheochromocytomas, whereas the Glu46Stop and Glu52Lys have been associated with VHL disease $[32,27]$. However, Rothberg et al. reported a VHL patient with two VHL gene mutations, Pro25Leu and Pro86Arg, in whom the Pro86Arg was considered more likely to be pathogenic than the Pro25Leu based on an allelic frequency of $0.5 \%$ of the latter variant in anonymized DNA samples [14]. This Pro25Leu variant was detected in other healthy VHL 
family members from Poland and North America [33,14]. In agreement with these observations, the Pro25Leu carrier in our family had no manifestations of the disease, suggesting that this variant does not represent a diseasecausing mutation.

\section{Conclusion}

The Ser80Ile mutation of the $v h l$ gene in a large Hungarian kindred was found to be associated with VHL type 2 presenting with both pheochromocytoma and renal cell cancer. Therefore, patients with this mutation require careful surveillance, including search for pheochromocytoma. The Pro25Leu variant in this family apeared to be neutral, but its co-existence made genetic counseling difficult.

\section{Abbreviations}

VHL: von Hippel-lindau disease; pVHL: von HippelLindau protein; HIF: hypoxia inducible factor.

\section{Competing interests}

The author(s) declare that they have no competing interests.

\section{Authors' contributions}

Acquisition of data: AP, KB, PG, FF performed the molecular biological analysis, AP, FF and IL participated in alignment analysis and in three dimensional protein modeling, MT and KR obtained the clinical data. Analysis and interpretation of data: AP, FF, IL, MT and KR. Drafting of the manuscript: AP, KB, PG, MT, IL and KR. Critical revision of the manuscript for important intellectual content: AP, IL, MT and KR. Administrative, technical, or material support: AP, PG, KB, FF, IL, MT and KR. Study supervision: KR.

\section{Acknowledgements}

Written consent for publication was obtained from the patient or their relative. Supported by grants from the Hungarian Ministry of Public Health (EET 090/2006)

\section{References}

I. Latif F, Tory K, Gnarra J, Yao M, Duh FM, Orcutt ML, Stackhouse T, Kuzmin I, Modi W, Geil L, et al.: Identification of the von HippelLindau disease tumor suppressor gene. Science 1993, 260(5 II 2): 13|7-I320.

2. Friedrich CA: Genotype-phenotype correlation in von HippelLindau syndrome. Hum Mol Genet 200I, I0(7):763-767.

3. Maher ER, Webster AR, Richards FM, Green JS, Crossey PA, Payne SJ, Moore AT: Phenotypic expression in von Hippel-Lindau disease: correlations with germline VHL gene mutations. J Med Genet 1996, 33(4):328-332.

4. Neumann HP, Wiestler OD: Clustering of features of von Hippel-Lindau syndrome: evidence for a complex genetic locus. Lancet 1991, 337(8749): 1052-1054.

5. Maher ER, Iselius L, Yates JR, Littler M, Benjamin C, Harris R, Sampson J, Williams A, Ferguson-Smith MA, Morton N: Von HippelLindau disease: a genetic study. I Med Genet 1991, 28(7):443-447.

6. Iliopoulos O, Ohh M, Kaelin WG Jr: pVHLI9 is a biologically active product of the von Hippel-Lindau gene arising from internal translation initiation. PNAS 1998, 95(20): | |66|-I|666.
7. Schoenfeld A, Davidowitz EJ, Burk RD: A second major native von Hippel-Lindau gene product, initiated from an internal translation start site, functions as a tumor suppressor. PNAS 1998, 95(I 5):8817-8822.

8. Stebbins CE, Kaelin WG Jr, Pavletich NP: Structure of the VHLElonginC-ElonginB complex: implications for VHL tumor suppressor function. Science 1999, 284(54 I 3):455-46I.

9. Maxwell PH, Wiesener MS, Chang GW, Clifford SC, Vaux EC, Cockman ME, Wykoff CC, Pugh CW, Maher ER, Ratcliffe PJ: The tumour suppressor protein VHL targets hypoxia-inducible factors for oxygen-dependent proteolysis. Nature 1999, 399(6733):27|-275.

10. Ohh M, Park CW, Ivan M, Hoffman MA, Kim TY, Huang LE, Pavletich $\mathrm{N}$, Chau V, Kaelin WG: Ubiquitination of hypoxia-inducible factor requires direct binding to the beta-domain of the von Hippel-Lindau protein. Nat Cell Biol 2000, 2(7):423-427.

II. Pause A, Lee S, Worrell RA, Chen DY, Burgess WH, Linehan WM, Klausner RD: The von Hippel-Lindau tumor-suppressor gene product forms a stable complex with human CUL-2, a member of the Cdc53 family of proteins. PNAS 1997, 94(6):2|56-2|6|

12. Hoffman MA, Ohh M, Yang H, Klco JM, Ivan M, Kaelin WG Jr: von Hippel-Lindau protein mutants linked to type 2C VHL disease preserve the ability to downregulate HIF. Hum Mol Genet 2001, 10(10): 1019-1027.

13. van der Harst E, de Krijger RR, Dinjens WN, Weeks LE, Bonjer HJ, Bruining HA, Lamberts SW, Koper JW: Germline mutations in the vhl gene in patients presenting with phaeochromocytomas. Int J Cancer 1998, 77(3):337-340.

14. Rothberg PG, Bradley JF, Baker DW, Huelsman KM: Is the P25L a "real" VHL mutation? Mol Diagn 200I, 6(I):49-54.

15. Pettman RK, Crowley A, Riddell C, Ludman MD: VHL P25L is not a pathogenic von Hippel-Lindau mutation: a family study. Mol Diagn Ther 2006, 10(4):239-242.

16. Patocs A, Karadi E, Toth M, Varga I, Szucs N, Balogh K, Majnik J, Glaz $\mathrm{E}$, Racz K: Clinical and biochemical features of sporadic and hereditary phaeochromocytomas: an analysis of $4 \mathrm{l}$ cases investigated in a single endocrine centre. Eur $J$ Cancer Prev 2004, I3(5):403-409.

17. O'Sullivan O, Suhre K, Abergel C, Higgins DG, Notredame C: 3Dcoffee : Combining protein sequences and structures within multiple sequence alignments. I Mol Biol 2004, 340:385-395

18. Grantham R: Amino acid difference formula to help explain protein evaluation. Science 1974, I 85:862-864.

19. Tavtigian SV, Deffenbaugh AM, Yin L, Judkins T, Scholl T, Samollow PB, de Silva D, Zharkikh A, Thomas A: Comprehensive statistical study of 452 BRCAI missense substitutions with classification of eight recurrent substitution as neutral. J Med Genet 2006, 43(4):295-305.

20. Mathe E, Olivier M, Kato S, Ishioka C, Hainaut P, Tavtigian SV: Computational approaches for predicting the biological effect of p53 missense mutations: a comparison of three sequence analysis based methods. Nucleic Acids Res 2006, 34(5): I 3 I 7 - I 325.

21. Website title [http://agvgd.iarc.fr]

22. Guex N, Peitsch MC: SWISS-MODEL and the Swiss-PdbViewer: an environment for comparative protein modeling. Electrophoresis 1997, I8(15):27| 4-2723.

23. Chen F, Kishida T, Yao M, Hustad T, Glavac D, Dean M, Gnarra JR, Orcutt ML, Duh FM, Glenn G, et al.: Germline mutations in the von Hippel-Lindau disease tumor suppressor gene: correlations with phenotype. Hum Mutat 1995, 5(1):66-75.

24. Assadi F, Brackbill EL: Bilateral pheochromocytomas and congenital anomalies associated with a de novo germline mutation in the von Hippel-Lindau gene. Am J Kidney Dis 2003, 4I(I): E3.

25. Woodward ER, Eng C, McMahon R, Voutilainen R, Affara NA, Ponder BA, Maher ER: Genetic predisposition to phaeochromocytoma: analysis of candidate genes GDNF, RET and VHL. Hum Mol Genet 1997, 6(7): 105I-1056.

26. Glavac D, Neumann HP, Wittke C, Jaenig H, Masek O, Streicher T, Pausch F, Engelhardt D, Plate $\mathrm{KH}$, Hofler $\mathrm{H}$, et al:: Mutations in the VHL tumor suppressor gene and associated lesions in families with von Hippel-Lindau disease from central Europe. Hum Genet 1996, 98(3):27I-280. 
27. Dollfus H, Massin P, Taupin P, Nemeth C, Amara S, Giraud S, Beroud C, Dureau P, Gaudric A, Landais $P$, et al.: Retinal hemangioblastoma in von Hippel-Lindau disease: a clinical and molecular study. Invest Ophth Vis Sci 2002, 43(9):3067-3074.

28. Crossey PA, Richards FM, Foster K, Green JS, Prowse A, Latif F, Lerman MI, Zbar B, Affara NA, Ferguson-Smith MA, et al.: Identification of intragenic mutations in the von Hippel-Lindau disease tumour suppressor gene and correlation with disease phenotype. Hum Mol Genet 1994, 3(8): I303-1308.

29. Bluyssen HA, Lolkema MP, van Beest M, Boone M, Snijckers CM, Los M, Gebbink MF, Braam B, Holstege FC, Giles RH, et al:: Fibronectin is a hypoxia-independent target of the tumor suppressor VHL. FEBS Lett 2004, 556(I-3): I37-I42.

30. Miller F, Kentsis A, Osman R, Pan ZQ: Inactivation of VHL by tumorigenic mutations that disrupt dynamic coupling of the pVHL.hypoxia-inducible transcription factor-Ialpha complex. J Biol Chem 2005, 280(9):7985-7996.

31. Guerois R, Nielsen JE, Serrano L: Predicting changes in the stability of proteins and protein complexes: a study of more than 1000 mutations. J Mol Biol 2002, 320(2):369-387.

32. Ruiz-Llorente S, Bravo J, Cebrian A, Cascon A, Pollan M, Telleria D Leton R, Urioste M, Rodriguez-Lopez R, de Campos JM, et al.: Genetic characterization and structural analysis of VHL Spanish families to define genotype-phenotype correlations. Hum Mutat 2004, 23(2): 160-169.

33. Cybulski C, Krzystolik K, Murgia A, Gorski B, Debniak T, Jakubowska A, Martella M, Kurzawski G, Prost M, Kojder I, et al.: Germline mutations in the von Hippel-Lindau (VHL) gene in patients from Poland: disease presentation in patients with deletions of the entire VHL gene. J Med Genet 2002, 39(7):E38.

\section{Pre-publication history}

The pre-publication history for this paper can be accessed here:

http://www.biomedcentral.com/1471-2350/9/29/prepub

Publish with Biomed Central and every scientist can read your work free of charge

"BioMed Central will be the most significant development for disseminating the results of biomedical research in our lifetime. "

Sir Paul Nurse, Cancer Research UK

Your research papers will be:

- available free of charge to the entire biomedical community

- peer reviewed and published immediately upon acceptance

- cited in PubMed and archived on PubMed Central

- yours - you keep the copyright 